\title{
HUBUNGAN FAKTOR PEKERJAAN TERHADAP KEJADIAN KATARAK NUKLEARIS
}

\author{
Uun Kurniasih*Lien Herlina**, Siti Ni'mawati**
}

\begin{abstract}
ABSTRAK
Pekerjaan dengan paparan sinar matahari merupakan faktor risiko terjadinya katarak. Paparan sinar matahari yang lama cenderung menderita katarak khususnya nuklearis.Tujuan dari penelitian ini adalah untuk membuktikan hubungan faktor pekerjaan terhadap kejadian katarak nuklearis.Jenis penelitian ini adalah penelitian deskriptif korelasi dengan pendekatan cross sectional study.Jumlah sampel sebanyak 52 orang penentuan sampelnya dengan menggunakan purposive sampling. Pengumpulan data akan dilakukan oleh peneliti, dengan cara observasi dan wawancara dan dianalisa secara statistika menggunakan uji Chi Square $\left(\mathrm{X}^{2}\right)$. Dari hasil uji statistika didapatkan bahwa dari hasil tabulasi silang ada kecenderungan faktor pekerjaan karena paparan sinar matahari dengan katarak nuklearis, sedangkan berdasarkan uji Chi Square tidak ada hubungan antara faktor pekerjaan karena paparan sinar matahari dengan katarak nuklearis dengan nilai $\quad \mathrm{p}=0,795(\mathrm{p}>$ $0,1)$.
\end{abstract}

Kata Kunci : Faktor pekerjaan katarak nuklearis

\begin{abstract}
Work with exposure to sunlight is a risk factor for cataracts. Long exposure to the sun tend to suffer from cataracts, especially nuklearis. The purpose of this study is to prove the correlation between the incidence of cataracts nuklearis work. This research is a descriptive study with cross -sectional correlation study. Total sample of 52 people who were taken through the large sample formula in which the determination of the sample by using purposive sampling. The data obtained by observation and interviews, and analyzed statistically using Chi Square ( X2 ).while based on Chi Square test was no association between occupational factors as sun exposure with cataract nuklearis with $\mathrm{p}=0.795(\mathrm{p}>0.1)$.

Keywords : Occupational factors, cataract nuklearis
\end{abstract}

\footnotetext{
* Staf Pengajar Program Studi S1 Keperawatan STIKes Cirebon

** Staf Pengajar Program Studi D III Keperawatan STIKes Cirebon

***Alumni D III Keperawatan STIKes Cirebon Lulus Tahun 2013
} 


\section{LATAR BELAKANG}

Indera penglihatan merupakan salah satu alat tubuh manusia yang mempunyai fungsi sangat penting untuk memungkinkan manusia menerima informasi dari lingkungan kehidupan sekitarnya sehingga mampu beradaptasi dan mempertahankan hidup dalam lingkungannya dan menghindarkan diri dari berbagai ancaman yang mungkin terjadi. Oleh sebab itu kebutaan dan gangguan penglihatan merupakan masalah kesehatan masyarakat. Kebutaan karena katarak dapat menyebabkan berkurangnya produktifitas maupun sumber daya manusia serta membutuhkan biaya yang cukup besar untuk pengobatannya. ${ }^{1}$

Katarak menyebabkan $48 \%$ kebutaan di dunia yang diderita oleh 18 juta orang (WHO). Di Amerika Serikat, katarak mencapai 42\% untuk pasien berumur 52-64 tahun, 60\% untuk mereka yang berusia 65-74 tahun, dan 91\% untuk lansia yang berumur 75-85 tahun. ${ }^{2}$

Di Indonesia katarak menjadi penyebab kebutaan nomor satu $(0,78 \%)$, Sejak saat itu kebutaan di Indonesia dicanangkan sebagai Bencana kebutaan Nasional.Selain itu,Indonesia memiliki angka penderita katarak tertinggi di Asia Tenggara dan menduduki urutan ketiga di dunia, yaitu 1,5\% dari jumlah penduduk, yang berarti lebih dari 3 juta orang menderita katarak. $^{3}$

Masyarakat Indonesia memiliki kecenderungan mengalami katarak 15 tahun lebih cepat dibandingkan di negara lain di daerah sub tropis. Sekitar 16-22\% penderita katarak berusia dibawah 55 tahun. $^{4}$

Laporan Nasional Riskesdas 2007 melaporkan prevalensi katarak umur 30 tahun ke atas (berdasarkan diagnosis tenaga kesehatan dan/atau gejala katarak) sebesar $17,4 \%$. (4) Sedangkan prevalensi katarak pada kelompok usia 40 tahun keatas pada masyarakat di Jawa Barat tahun 2005 dilaporkan sebesar 22,8\%. ${ }^{5}$

Hasil survey kebutaan dan kesehatan mata di Jawa Barat tahun 2005 melaporkan penyebab kebutaan terbesar pada kelompok usia 40 tahun keatas adalah katarak $(80,6 \%) .{ }^{3}$

Terjadinya katarak di duga karena proses multifaktor, salah satunya adalah faktor pajanan kronis terhadap sinar ultra violet. Pekerjaan dalam hal ini berhubungan dengan paparan sinar ultraviolet, dimana sinar UV merupakan faktor resiko terjadinya katarak. Sinar Ultraviolet yang berasal dari sinar matahari akan diserap oleh protein lensa dan kemudian akan menimbulkan reaksi fotokimia sehingga terbentuk radikal bebas atau spesies oksigen yang bersifat sangat reaktif. Reaksi tersebut akan mempengaruhi struktur protein lensa, selanjutnya menyebabkan kekeruhan lensa yang disebut katarak. ${ }^{6}$

Berdasarkan data dari Dinas Kesehatan Kota Cirebon tahun 2012, angka kebutaan katarak diperkirakan 318 dari jumlah penduduk \pm 304.152. Sedangkan insidensi katarak setiap tahun adalah 1 permil dari jumlah penduduk. ${ }^{7}$

Sedangkan data dari Badan Pusat Statistik Kota Cirebon tahun 2012, penduduk 10 tahun ke atas yang bekerja menurut Lapangan Usaha Utama Tahun 2009 adalah Pertanian : 2.445, Industri pengolahan : 7.485, Perdagangan, hotel dan restoran : 58.839, Jasa-jasa : 27.402, dan lainnya 32.343. Jumlah tenaga kerja seluruhnya $128.514 .{ }^{8}$ Penelitian ini bertujuan untuk mengetahui hubungan faktor pekerjaan terhadap kejadian katarak nuklearis di UPTD Pelayanan Kesehatan Khusus Dinas Kesehatan Kota Cirebon.

\section{METODE PENELITIAN}

Penelitian ini menggunakan desain studi deskriptif korelasi dengan pendekatan cross sectional studyyaitu penelitian untuk mengetahui ada tidaknya hubungan antara dua variabel.Variabel dalam penelitian ini adalah faktor pekerjaan (variabel independen) dan kejadian katarak nukearis (variabel dependen).Populasi dalam penelitian ini adalah pasien katarak yang bekerja di luar gedung.Jadi populasi dalam penelitian ini pada tahun 2012 adalah 
107. Sampel penelitian ini berdasarkan kriteria inklusi dan eksklusi. Kriteria inklusi dan eksklusi dalam penelitian ini adalah:

1. Kriteria inklusi

1) Pekerjaan dengan paparan sinar matahari

2) Umur 35 - 60 tahun.

3) Tidak termasuk dalam kriteria ekslusi

4) Bersedia menjadi responden

2. Kriteria ekslusi

1) Usia $<35$ tahun dan $>60$ tahun.

2) Menderita penyakit DM

3) Perokok (sehari 2 pak/32 batang)

4) Riwayat trauma pada lensa mata

5) Diare kronis

6) Peminum alkohol

7) Menggunakan obat-obat steroid secara rutin 6 bulan terakhir.

8) Tidak bersedia menjadi responden

Dalam penelitian ini perhitungan sampel menggunakan rumus Taro Yamane :

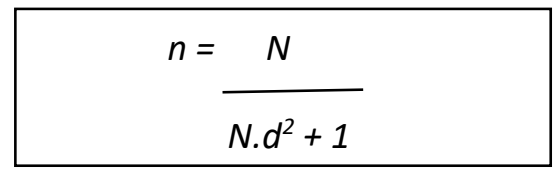

Pengumpulan data pada penelitian ini menggunakan wawancara dan kuesioner observasi dengan alat bantusnellen chart / E chart (kartu huruf/abjad), pinhole (cakram berlubang), dan senter untuk mengukur visus/tajam penglihatan dan kekeruhan lensa. Sumber data yang akan digunakan dalam penelitian ini adalah sumber data primer yaitu diambil langsung dari responden dan data sekunder yang diambil dari dokumen patient list katarak Kota Cirebon. Pengumpulan data akan dilakukan oleh peneliti, dengan cara dilakukan pemeriksaan tajam penglihatan dan kekeruhan lensa kepada responden dilanjutkan dengan wawancara. Responden terlebih dahulu akan diberikan penjelasan dan menandatangani informed consent kesediaan untuk menjadi responden penelitian. Analisis data hasil analisis ini nantinya akan memberikan gambaran deskripsi dari variabel-variabel yang diteliti.Adapun rumus yang digunakan adalah :

$$
p=\frac{f}{n}_{X 100 \%}
$$

Analisa bivariat uji hipotesis yang digunakan uji Chi Square $\left(\mathrm{X}^{2}\right)$.

\section{HASIL PENELITIAN}

\section{Faktor Pekerjaan}

Dilakukan untuk mengetahui distribusi frekuensi dari masing-masing variabel sehingga memberikan gambaran dari masing-masing variabel yang diteliti. 
Tabel 1.Distribusi Responden Menurut Faktor Pekerjaan Karena Paparan Sinar Matahari

\begin{tabular}{llll}
\hline No & Paparan Sinar Matahari & Jumlah & $\%$ \\
\hline 1. & $<7$ jam & 15 & 28,8 \\
2. & 27 jam & 57 & 71,2 \\
\hline & Total & 52 & 100 \\
\hline
\end{tabular}

Dari tabel 1 didapatkan dari 52 responden penderita katarak yang bekerja di luar gedung, proporsi yang lebih besar ada pada kelompok responden yang terpapar sinar matahari $\geq 7$ jam, yaitu sebanyak 37 orang $(71,2 \%)$.

\section{Kejadian Katarak Nuklearis}

Tabel 2. Distribusi Responden Menurut Kejadian Katarak Nuklearis

\begin{tabular}{llll}
\hline No & Katarak & Jumlah & $\%$ \\
\hline 1. & Nuklearis & 28 & 53,8 \\
2. & Non Nuklearis & 24 & 46,2 \\
\hline & Total & 52 & 100 \\
\hline
\end{tabular}

Dari tabel 2 didapatkan dari 52 responden penderita katarak yang bekerja di luar gedung, proporsi terbanyak ada pada kelompok responden yang menderita katarak nuklearis, yaitu 28 orang $(53,8 \%)$.

\section{Faktor Pekerjaan Terhadap Kejadian Katarak Nuklearis}

Analisis bivariat dilakukan untuk melihat hubungan antara variabel independen dengan variabel dependen dengan batas kemaknaan $\mathrm{p}=0,1$.

Tabel 3 Hubungan Faktor Pekerjaan Terhadap Kejadian Katarak Nuklearis

\begin{tabular}{|c|c|c|c|c|c|c|c|}
\hline \multirow{2}{*}{ No } & \multirow{2}{*}{$\begin{array}{l}\text { Paparan Sinar } \\
\text { Matahari }\end{array}$} & \multicolumn{4}{|c|}{ Katarak } & \multirow{2}{*}{ Total } & \multirow{2}{*}{$\mathrm{P}$} \\
\hline & & Nuklearis & $\%$ & $\begin{array}{l}\text { Non } \\
\text { Nuklearis }\end{array}$ & $\%$ & & \\
\hline 1. & $<7$ jam & 9 & 17,3 & 6 & 11,6 & 15 & \multirow{2}{*}{0,795} \\
\hline 2. & $\geq 7$ jam & 19 & 36,5 & 18 & 34,6 & 37 & \\
\hline & Total & 28 & 53,8 & 24 & 46,2 & 52 & \\
\hline
\end{tabular}


Dari tabel 3 didapatkan dari 52 responden penderita katarak yang bekerja di luar gedung, didapatkan prosentase lebih besar terdapat pada kelompok responden yang terpapar sinar matahari $\geq 7$ jam dan menderita katarak nuklearis yaitu sebanyak 19 orang $(36,5 \%)$.

Dari perhitungan dengan menggunakan uji statistik Chi Square didapatkan nilai probability $=0,795(\mathrm{p}>0,1 \rightarrow$ Ho diterima), maka dapat disimpulkan bahwa tidak ada hubungan antara faktor pekerjaan dengan kejadian katarak nuklearis.

\section{PEMBAHASAN}

Faktor Pekerjaan

Dari hasil penelitian terhadap 52 responden yang diuji, proporsi lebih besar ada pada kelompok responden yang terpapar sinar matahari $\geq 7$ jam sebanyak 37 orang $(71,2 \%)$, sehingga dapat disimpulkan bahwa sebagian besar responden yang bekerja di luar gedung terpapar sinar matahari selama $\geq 7$ jam.

\section{Kejadian Katarak Nuklearis}

Dari hasil penelitian terhadap 52 responden yang diuji, proporsi lebih besar ada pada kelompok responden yang menderita katarak nuklearis yaitu sebanyak 28 orang $(53,8 \%)$, sehingga dapat disimpulkan bahwa sebagian besar responden yang bekerja di luar gedung menderita katarak nuklearis.

\section{Hubungan Faktor Pekerjaan Terhadap Kejadian Katarak Nuklearis Tabulasi silang}

Dari hasil penelitian terhadap 52 responden yang diuji, 19 orang $(36,5 \%)$ terpapar sinar matahari $\geq 7$ jam dan menderita katarak nuklearis, sehingga dapat disimpulkan bahwa sebagian besar responden yang bekerja di luar gedung terpapar sinar matahari $\geq 7$ jam menderita katarak nuklearis.

Hasil ini sejalan dengan penelitian yang dilakukan oleh Wong and Ho (1993) dan Leske et al (2003) yang menunjukkan bahwa paparan sinar matahari yang lama cenderung menderita katarak khususnya nuklearis. ${ }^{(19)}$ Dan juga sejalan dengan penelitian yang dilakukan oleh Neale et al. yang melaporkan adanya hubungan positif yang kuat antara pekerjaan yang terpapar sinar matahari pada usia antara 20-29 tahun dengan katarak nuklear. Paparan yang terjadi di usia lebih lanjut mempunyai hubungan lemah.

Pekerja di luar gedung, pekerjaan dalam hal ini erat kaitannya dengan paparan sinar matahari, dimana sinar ultraviolet merupakan faktor risiko terjadinya katarak. Sinar Ultraviolet yang berasal dari sinar matahari akan diserap oleh protein lensa dan kemudian akan menimbulkan reaksi fotokimia sehingga terbentuk radikal bebas atau spesies oksigen yang bersifat sangat reaktif. Reaksi tersebut akan mempengaruhi struktur protein lensa, selanjutnya menyebabkan kekeruhan lensa yang disebut katarak.

Berdasarkan hasil perhitungan uji statistik Chi Square, didapatkan nilai $\mathrm{p}=0,795$ ( $\mathrm{p}>$ $0,1 \rightarrow$ Ho diterima), yang disimpulkan bahwa tidak ada hubungan faktor pekerjaan dengan kejadian katarak nuklearis.

Hasil ini tidak sejalan dengan penelitian yang dilakukan oleh Wong and Ho, Leske et al ataupun Neale et al. Tetapi sejalan dengan penelitian yang dilakukan oleh Brilliant dan kawan-kawan yang melaporkan bahwa pajanan terhadap sinar matahari selama 12 jam menimbulkan katarak 3,8 kali lebih banyak dibandingkan hanya terpajan rata-rata 7 jam sehari. 


\section{SIMPULAN}

Berdasarkan hasil penelitian dan pembahasan dapat disimpulkan, dilihat dari hasil tabulasi silang ada kecenderungan faktor pekerjaan karena paparan sinar matahari terhadap kejadian katarak nuklearis, tetapi berdasarkan uji Chi Square tidak ada hubungan faktor pekerjaan terhadap kejadian katarak nuklearis dengan nilai $p=0,795(p>0,1)$.

\section{SARAN}

1. Bagi Instansi Kesehatan

Bagi Dinas Kesehatan Kota Cirebon dan UPTD Pelayanan Kesehatan Khusus agar membuat perencanaan program Kesehatan Indera yang berkoordinasi dengan lintas program Kesehatan Kerja dan Promosi Kesehatan dalam Penanggulangan Gangguan Penglihatan dan Kebutaan Katarak Kota Cirebon.

2. Bagi Masyarakat

Memberikan informasi kepada masyarakat melalui poster, leaflet ataupun penyuluhan tentang penyebab dan tanda-tanda terjadinya katarak serta upaya pencegahan penyakit katarak yang disebabkan karena pekerjaan yang terpapar sinar matahari, yang bisa dilakukan melalui kegiatan kemasyarakatan Sapa Warga.

3. Bagi Pendidikan

Agar difasilitasi alat peraga tentang panca indera penglihatan di setiap ruangan kelas dan melengkapi buku-buku tentang sistem panca indera, khususnya panca indera penglihatan.

4. Bagi Peneliti

Bagi peneliti selanjutnya agar meneliti faktor lain sebagai penyebab terjadinya katarak nuklearis.

\section{DAFTAR PUSTAKA}

1. Kementerian Kesehatan RI. Pedoman Pelayanan Kesehatan Indera Penglihatan Di Puskesmas:Jakarta;2010.

2. Prof. dr H. Azwar Agoes, DAFK, SpFK (K). DR. Dr. H. Achdiat Agoes, SpS(K). DR. H. Arizal Agoes, SpB, SpU. Penyakit Di Usia Tua.Jakarta:Penerbit Buku Kedokteran EGC;2010.

3. Departemen Kesehatan RI. Rencana Strategis Nasional Penanggulangan Gangguan Penglihatan dan Kebutaan (PGPK) untuk Mencapai Vision 2020:Jakarta. Depkes RI;2003.

4. Badan Penelitian dan Pengembangan Kesehatan, Departemen Kesehatan RI. Laporan Nasional Riset Kesehatan Dasar 2007:Jakarta.Depkes RI ;2008.

5. Rumah Sakit Mata Cicendo, Fakultas Kedokteran Universitas Padjadjaran, Hellen Keller Internasional Indonesia:Survei Kebutaan dan Kesehatan Mata di Jawa Barat tahun 2005. Bandung;2006.

6. Sinha R et al. Etiopathogenesis of Cataract : Journal Review. Indian Journal of Ophtalmology Vol. 57 No.3: May-June 2009.p 248-249

7. Dinas Kesehatan Kota Cirebon:Profil Kesehatan Kota Cirebon;2012

8. Badan Pusat Statistik Kota Cirebon. Kota CirebonDalam Angka, Cirebon in figures. 2012. [diakses tanggal 10 Oktober 2013] 